\title{
The effect of dietary $n-3$ fatty acids on serum concentrations of C-reactive protein: a dose-response study
}

\author{
Trine Madsen $^{1}$, Jeppe H. Christensen ${ }^{2}$, Mogens Blom ${ }^{3}$ and Erik B. Schmidt ${ }^{1}$ \\ ${ }^{1}$ Department of Cardiology, Aalborg Hospital, Denmark \\ ${ }^{2}$ Department of Nephrology, Aalborg Hospital, Denmark \\ ${ }^{3}$ Department of Clinical Biochemistry, Hjфrring/Brønderslev Hospital, Denmark
}

(Received 10 May 2002 - Revised 14 November 2002 - Accepted 26 November 2002)

\begin{abstract}
C-reactive protein (CRP) is a sensitive marker for low-grade inflammation. Long-chain $n$-3 polyunsaturated fatty acids (PUFA) have anti-inflammatory effects. The objective of the present study was to investigate the effect on serum levels of CRP of $n$-3 PUFA at two different doses. We also investigated correlations between CRP and the cellular contents of PUFA. Sixty healthy volunteers (twenty-five women and thirty-five men) were randomly assigned to three treatment groups in a double-blind design. The subjects received a supplement of either $6.6 \mathrm{~g}$ $n$-3 PUFA/d, 2.0 g n-3 PUFA/d or placebo (olive oil) for 12 weeks. CRP was measured using a highly sensitive assay. The median serum CRP concentration was $0.78 \mathrm{mg} / \mathrm{l}$. No significant correlations were found between CRP and the content of $n$-3 PUFA in granulocytes or platelets. Subjects receiving $n$-3 PUFA had a significant $(P<0.01)$ increase in the cellular contents of $20: 5 n-3,22: 5 n-3$ and $22: 6 n-3$, with the largest increase occurring in the group receiving $6.6 \mathrm{~g}$ PUFA/d. A significant $(P<0 \cdot 01)$ decrease in cellular content of $18: 2 n-6$ and $20: 4 n-6$ was observed simultaneously. Serum CRP concentrations, however, were unaffected by the PUFA-containing supplements. The present study shows that dietary supplementation with PUFA-containing supplements has no effect on serum concentrations of CRP, measured with a highly sensitive assay, in healthy subjects.
\end{abstract}

Fatty acids: Fish oil: Inflammation: C-reactive protein

C-reactive protein (CRP) is an acute-phase reactant produced in the liver in response to the cytokine interleukin 6 released from activated leucocytes (Castell et al. 1990). Infection, inflammatory disease, burns, trauma, surgery and tissue infarction cause changes in plasma CRP concentrations, which can increase more than 100-fold (Steel \& Whitehead, 1994). In daily clinical practice CRP concentrations $<10 \mathrm{mg} / \mathrm{l}$ are often considered as clinically insignificant. However, highly sensitive (hs) CRP assays are now available to detect CRP concentrations well below the lower limit of most assays used in clinical settings and, hence, biochemical signs of low-grade inflammation.

There is growing evidence that chronic low-grade inflammation has an important role in the initiation and progression of atherosclerosis (Ross, 1999). Therefore, a significant part of cardiovascular research in recent years has involved the measurement of hs-CRP. Slightly elevated baseline concentrations of CRP are predictive of a higher risk of future cardiovascular morbidity and mortality in apparently healthy people (Koenig et al. 1999), and it has been suggested that measurement of hs-CRP should be included in coronary risk assessment (Ridker et al. 1997; Ridker, 2001).

The marine $n-3$ polyunsaturated fatty acids (PUFA), eicosapentaenoic acid (20:5n-3) and docosahexaenoic acid (22: $6 n-3)$, found primarily in fish and fish oil, possess anti-inflammatory properties (Schmidt \& Dyerberg, 1989; James et al. 2000; Calder, 2001), which may contribute to their cardioprotective effect (Schmidt, 1997). The objective of the present study was to examine the possible correlations between baseline CRP concentrations and the content of n-3 and n-6 fatty acids in granulocytes and platelets, and to investigate the effect of two different doses of $n$-3 PUFA supplementation on serum levels of CRP.

\section{Subjects and methods}

Subjects

Sixty healthy volunteers (twenty-five women and thirtyfive men) were recruited from the medical staff, bloodbank employees and students in Aalborg, Denmark. None 
of the subjects had any known diseases or took any medication at the time of investigation. The mean age was 38 (range 21-57) years.

\section{Study design}

The present work is a substudy of a dose-response study focusing on $n$-3 PUFA and heart-rate variability (Christensen et al. 1999). The study design was double-blind and placebocontrolled with regard to the three dietary groups (see later). The protocol was approved by the regional Ethical Committee and written informed consent was obtained from all the subjects.

\section{Dietary supplements}

The subjects were randomly assigned to one of three intervention groups. One group received a supplement of $6.6 \mathrm{~g}$ $n$-3 PUFA/d, containing approximately $3.0 \mathrm{~g} 20: 5 n-3$ and 2.9 g $22: 6 n-3$ (ten capsules of Pikasol ${ }^{\circledR}$ (a reesterified triacylglycerol, EPAX 5500); Pronova Biocare A/S, Sandefjord, Norway). The second group received $2.0 \mathrm{~g} n-3$ PUFA $(0.9 \mathrm{~g} 20: 5 n-3$ and $0.8 \mathrm{~g} 22: 6 n-3$ in three capsules of Pikasol ${ }^{\circledR}$ ) and seven capsules of placebo (olive oil)/d. The third group received ten capsules of olive oil per $d$. One placebo capsule contained approximately $0.7 \mathrm{~g}$ olive oil. The subjects were randomised in blocks of ten and numbered consecutively. Treatment began at the time of allocation. The subjects took three capsules in the morning and seven capsules with the evening meal. The capsules were taken from two different boxes to maintain the blinding. The supplements were given daily for 12 weeks.

\section{Blood sampling}

Before and after 12 weeks of dietary supplementation, blood samples were drawn after an overnight fast of at least $10 \mathrm{~h}$ and immediately frozen at $-80^{\circ} \mathrm{C}$ for later analysis.

\section{Fatty acid analysis}

Granulocytes and platelets were isolated from whole blood, the lipids were extracted, and the fatty acids esterified as described earlier (Schmidt et al. 1991). The content of the different PUFA in granulocytes and platelets was measured using a Chrompack CP-9002 GC (Chrompack International, Middelburg, the Netherlands) and expressed as $\mathrm{g} / 100 \mathrm{~g}$ total fatty acids.

\section{Measurement of serum $C$-reactive protein}

Measurement of CRP was performed with a BNII nephelometer (Dade Behring Marburg GmbH, Marburg, Germany), which employs fixed-time kinetic measurements at $840 \mathrm{~nm}$. In this assay, polystyrene beads coated with monoclonal antibodies from mice bind CRP present in the serum samples, resulting in light-scattering aggregates proportional to the content of CRP. The particle enhancement makes the determination of values in the lower quartile of the reference range possible. The sensitivity of this assay $(0.17 \mathrm{mg} / \mathrm{l})$ is comparable with that of other hs-CRP assays such as ELISA (Macy et al. 1997). The calibration of the method ensures traceability to the primary reference material CRM 470. The method has been validated by others (Rifai et al. 1999). In our hands, the intra-run precision $(\mathrm{CV})$ was estimated to 2.9 and $3.0 \%$ at concentrations of 0.43 and $2.08 \mathrm{mg} / 1$ respectively.

\section{Statistical analysis}

The size of the study sample was based on an estimated SD $1.5 \mathrm{mg} / \mathrm{l}$, type 1 error $5 \%$ and type 2 error $20 \%$. Twenty subjects were required in each intervention group in order not to miss a $1.3 \mathrm{mg} / \mathrm{l}$ difference between the groups. Because the distribution of CRP values was skewed towards greater values, serum concentrations are presented as median values and interquartile ranges. The remaining variables are presented as mean values and standard deviations. Wilcoxon signed rank sum test was used to test for any differences within the groups before and after supplementation. Comparisons between groups were carried out using the Mann-Whitney $U$ test or, when more than two groups were involved, by Kruskal-Wallis one-way ANOVA. Differences in nominal data were evaluated by the $\chi^{2}$ test. Spearman's rank correlation test was used to assess relationships between variables. $P<0.05$ (two-tailed) was considered statistically significant. The SPSS software package (version 7.0; SPSS, Chicago, IL, USA) was used for all the analyses.

\section{Results}

\section{Before supplementation}

The median serum CRP concentration was 0.78 (range 0.44-1.48) $\mathrm{mg} / \mathrm{l}$. CRP concentrations were $<3 \mathrm{mg} / \mathrm{l}$ in $90 \%$ of the subjects. There was no significant difference in CRP levels between men and women (median value 0.69 (interquartile range $0.36-1.08$ ) v. 1.00 (interquartile range $0 \cdot 50-1.90) \mathrm{mg} / \mathrm{l}, P=0.15)$. In men, but not in women, CRP was positively correlated with the content of $18: 2 n-6$ in granulocytes and of $16: 0$ in both granulocytes and in platelets. However, these correlations disappeared in a multivariate linear stepwise regression analysis. No significant correlations were found between CRP and the content of any of the other PUFA, including $18: 1 n-9$, which olive oil is rich in (results not shown). CRP was positively correlated with BMI (Spearman's $\rho$ $0 \cdot 31, P=0 \cdot 015)$. The three intervention groups were comparable before supplementation with regard to age, sex, BMI and smoking status (Table 1), CRP concentrations (Table 2) and cellular content of fatty acids (Table 3 ).

\section{Dietary supplementation}

Serum CRP concentrations before and after the supplements are shown in Table 2 . There were no statistically significant differences in CRP concentrations before and after supplementation in any of the three groups and no differences between groups (Table 2 and Fig. 1). When subjects with CRP $>2 \mathrm{mg} / \mathrm{l}$ ( $n$ 11) were analysed separately, no difference with supplementation was found either. 
Table 1. Characteristics of the study participants before supplementation

(Mean values and standard deviations for twenty subjects per group)

\begin{tabular}{|c|c|c|c|c|c|c|c|c|c|c|c|c|c|}
\hline \multirow[b]{2}{*}{ Treatment group... } & \multicolumn{4}{|c|}{ Placebo } & \multicolumn{4}{|c|}{$2.0 \mathrm{~g} \mathrm{n}-3 \mathrm{PUFA} / \mathrm{d}$} & \multicolumn{4}{|c|}{$6.6 \mathrm{~g} n-3 \mathrm{PUFA} / \mathrm{d}$} & \multirow{2}{*}{$\begin{array}{c}\text { Statistical significance } \\
\text { of effect }\end{array}$} \\
\hline & Mean & SD & $n$ & $\%$ & Mean & SD & $n$ & $\%$ & Mean & SD & $n$ & $\%$ & \\
\hline Age (years) & 37 & 11 & & & 38 & 10 & & & 39 & 10 & & & NS \\
\hline Women & & & 8 & 40 & & & 8 & 40 & & & 9 & 45 & NS \\
\hline Men & & & 12 & 60 & & & 12 & 60 & & & 11 & 55 & NS \\
\hline BMI $\left(\mathrm{kg} / \mathrm{m}^{2}\right)$ & $24 \cdot 0$ & $2 \cdot 7$ & & & $25 \cdot 1$ & $2 \cdot 9$ & & & $24 \cdot 6$ & $10 \cdot 1$ & & & NS \\
\hline Current smoking $(n)$ & & & 5 & 20 & & & 6 & 20 & & & 5 & 20 & NS \\
\hline
\end{tabular}

PUFA, polyunsaturated fatty acid

Subjects receiving 2.0 or $6.6 \mathrm{~g} n-3$ PUFA/d for 12 weeks had a significant $(P<0.01)$ increase in cellular contents of $20: 5 n-3,22: 5 n-3$ and $22: 6 n-3$, with the largest increase occurring in the group receiving $6.6 \mathrm{~g}$ PUFA/d. Significant $(P<0.01)$ decreases in $18: 2 n-6$ and $20: 4 n-6$ were observed simultaneously in both granulocytes and platelets (Table 3).

\section{Discussion}

The median CRP concentrations in healthy populations are reported to be 1-2 mg/l (Rifai et al. 1999; Erlandsen \& Randers, 2000). In healthy subjects, baseline CRP concentrations are not subject to diurnal variation (Meier-Ewert et al. 2001) and, furthermore, appear tightly regulated over long periods of time, with some individuals having consistently higher values than others (Macy et al. 1997). Thus, measurement of hs-CRP provides a stable measure of chronic low-grade inflammation.

The fatty-acid composition of cell membranes reflects the dietary intake of these fatty acids (Brown et al. 1991). In the Western diet, the $n-6: n-3$ PUFA ratio has increased greatly over the past century (Simopoulos, 1999). In the course of inflammatory activation the $n-6$ PUFA, arachidonic acid (20:4n-6), is released from membrane phospholipids and metabolised to highly proinflammatory eicosanoids such as leukotriene $\mathrm{B}_{4}$ (Lee \& Austen, 1986). When the intake of marine $n-3$ PUFA is high, eicosapentaenoic acid $(20: 5 n-3)$ and docosahexaenoic acid (22:6n-3) partially replace arachidonic acid in the cell membranes, and eicosapentaenoic acid competes with arachidonic acid as a substrate for eicosanoids, leading to formation of the less active leucotriene $\mathrm{B}_{5}$. The balance of $n$-6- and $n$-3-derived eicosanoids is therefore shifted towards a mixture with decreased inflammatory activity (James et al. 2000). Other mechanisms by which $n$-3 PUFA exert their anti-inflammatory properties include a reduced production of the major cytokine mediators of inflammation, interleukin 1 and tumour necrosis factor (Caughey et al. 1996), attenuation of leucocyte adhesion to the endothelium (De Caterina et al. 2000) and impaired leucocyte chemotaxis (Schmidt \& Dyerberg, 1989).

In accordance with this, a beneficial effect of $n$-3 PUFA has been observed in patients with inflammatory diseases, such as rheumatoid arthritis (James \& Cleland, 1997) and inflammatory bowel disease (Belluzzi et al. 2000).

The specific effect of dietary $n-3$ PUFA on CRP concentrations has scarcely been studied. Ernst et al. (1991) found that 3 weeks of supplementation with $n-3$ fatty acids reduced the concentrations of several acute-phase proteins in young healthy males and altered the pattern of change following exercise. CRP concentrations, however, remained below the detection limit of the only moderately sensitive assay used $(2 \cdot 8 \mathrm{mg} / \mathrm{l})$.

In the present study, serum CRP levels were not reduced by 12 weeks of dietary supplementation with 2.0 or $6.6 \mathrm{~g}$ $n-3$ PUFA. Our present subjects were all apparently healthy and, accordingly, had low baseline concentrations of CRP. Little, if any, reduction of CRP was therefore to be expected.

Chan et al. (2002) recently reported 4.4-fold greater CRP concentrations in obese individuals compared with lean healthy controls. Atorvastatin significantly decreased CRP in the obese subjects, but this was not seen with PUFA given in doses of approximately $3.4 \mathrm{~g} / \mathrm{d}$. The authors suggested that the lack of effect of fish oil on CRP might be due to a small but deleterious effect of $n$-3 PUFA on insulin sensitivity, which would tend to stimulate CRP synthesis (Campos \& Baumann, 1992) and counteract a supressive effect of $n$-3 PUFA on proinflammatory cytokines. Chan et al. (2002) used a dose of fish oil that was about $50 \%$ that of our $6.6 \mathrm{~g} / \mathrm{d}$ group, and the study went on for only 6 weeks compared with 12 weeks in our present study.

Table 2. Serum C-reactive protein values in the three treatment groups before and after 12 weeks of dietary supplementation* (Median values and interquartile ranges for twenty subjects per group)

\begin{tabular}{|c|c|c|c|c|c|c|}
\hline \multirow{2}{*}{$\begin{array}{l}\text { Treatment group... } \\
\text { Time (weeks)... }\end{array}$} & \multicolumn{2}{|c|}{ Placebo } & \multicolumn{2}{|c|}{$2.0 \mathrm{~g} n-3$ PUFA/d } & \multicolumn{2}{|c|}{$6.6 \mathrm{~g} n-3$ PUFA/d } \\
\hline & 0 & 12 & 0 & 12 & 0 & 12 \\
\hline $\begin{array}{l}\text { Median } \\
\text { Interquartile range }\end{array}$ & $\begin{array}{c}0.67 \\
0.30-1.54\end{array}$ & $\begin{array}{c}0.63 \\
0.36-1.01\end{array}$ & $\begin{array}{c}0.69 \\
0.41-1.21\end{array}$ & $\begin{array}{c}0.67 \\
0.26-2 \cdot 81\end{array}$ & $\begin{array}{c}1.07 \\
0.67-2 \cdot 36\end{array}$ & $\begin{array}{c}0.88 \\
0.54-1.95\end{array}$ \\
\hline
\end{tabular}

PUFA, polyunsaturated fatty acid.

${ }^{*}$ For details of subjects, supplements and procedures, see Table 1 and p. 518. 


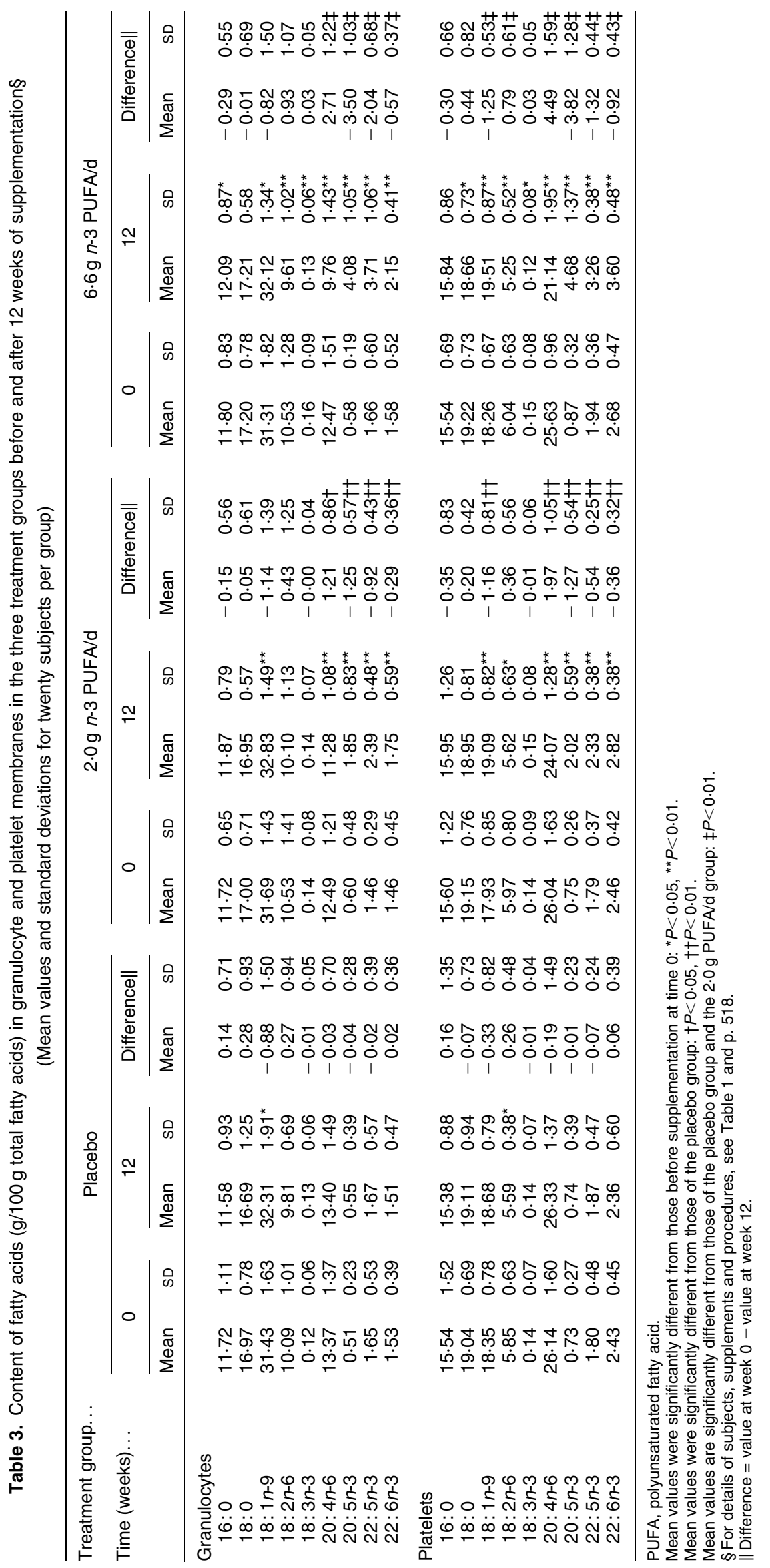



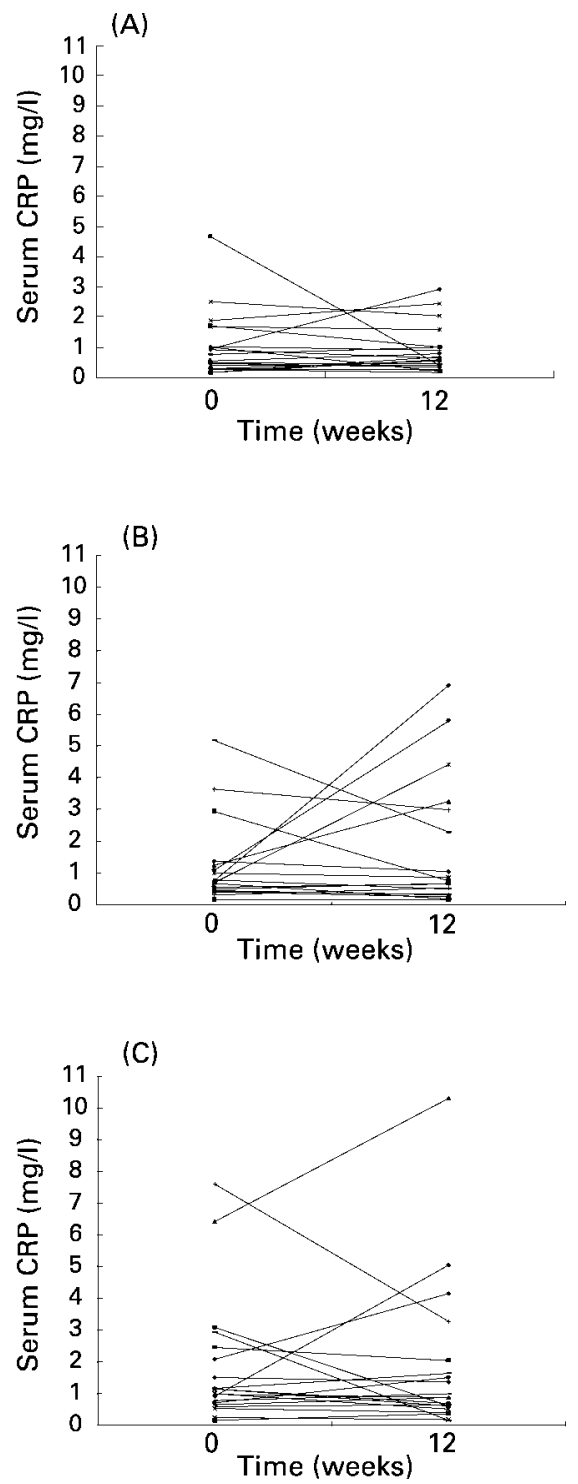

Fig. 1. Serum $\mathrm{C}$-reactive protein (CRP) concentrations at baseline and after 12 weeks of dietary supplementation with placebo (A), $2.0 \mathrm{~g} n-3$ polyunsaturated fatty acids/d (B) or $6.6 \mathrm{~g} n-3$ polyunsaturated fatty acids/d (C). For details of subjects, supplements and procedures, see Table 1 and p. 518.

There is, however, some evidence that dietary supplementation with $n$-3 PUFA might have an effect on elevated CRP concentrations. In a placebo-controlled intervention study, a statistically significant decrease in CRP from 21 to $17 \mathrm{mg} / \mathrm{l}$ was seen in patients with rheumatoid arthritis treated with $3.6 \mathrm{~g} \mathrm{n-3} \mathrm{PUFA/d} \mathrm{for} 12$ weeks, while CRP concentrations were unaltered among controls (Nielsen et al. 1992).

In a recent study involving 269 patients referred for coronary angiography due to clinical suspicion of coronary artery disease, we found that CRP concentrations were correlated independently and inversely with the content of $22: 6 n-3$ in granulocyte membranes (Madsen et al. 2001). It remains to be tested whether dietary $n-3$ PUFA supplementation actively lowers CRP concentrations in patients with stable coronary artery disease, who often have slightly elevated CRP (Tataru et al. 2000). In patients with acute coronary syndrome the inflammatory system is highly activated and this indicates a worse prognosis (Toss et al. 1997; Biasucci et al. 1999). It would be of particular interest to investigate the effect of $n$-3 PUFA on CRP concentrations and outcome in these high-risk patients.

In conclusion, 12 weeks of supplementation with $n-3$ PUFA had no effect on CRP in healthy subjects with low baseline CRP levels. However, it remains to be investigated whether intervention with $n-3$ PUFA has any effect on CRP and outcome in subjects with CHD and high CRP levels.

\section{Acknowledgements}

This study was supported by The Medical Research Foundation of the County of Northern Jutland.

\section{References}

Belluzzi A, Boschi S, Brignola C, Munarini A, Cariani G \& Miglio F (2000) Polyunsaturated fatty acids and inflammatory bowel disease. American Journal of Clinical Nutrition 71, 339S-342S.

Biasucci LM, Liuzzo G, Grillo RL, Caligiuri G, Rebuzzi AG, Buffon A, Summaria F, Ginnetti F, Fadda G \& Maseri A (1999) Elevated levels of C-reactive protein at discharge in patients with unstable angina predict recurrent instability. Circulation 99, 855-860.

Brown AJ, Pang E \& Roberts DC (1991) Persistent changes in the fatty acid composition of erythrocyte membranes after moderate intake of $n-3$ polyunsaturated fatty acids: study design implications. American Journal of Clinical Nutrition 54, $668-673$.

Calder PC (2001) Polyunsaturated fatty acids, inflammation, and immunity. Lipids 36, 1007-1024.

Campos SP \& Baumann H (1992) Insulin is a prominent modulator of the cytokine-stimulated expression of acute-phase plasma protein genes. Molecular and Cellular Biology 12, $1789-1797$.

Castell JV, Gomez-Lechon MJ, David M, Fabra R, Trullenque R \& Heinrich PC (1990) Acute-phase response of human hepatocytes: regulation of acute-phase protein synthesis by interleukin-6. Hepatology 12, 1179-1186.

Caughey GE, Mantzioris E, Gibson RA, Cleland LG \& James MJ (1996) The effect on human tumor necrosis factor alpha and interleukin 1 beta production of diets enriched in $n-3$ fatty acids from vegetable oil or fish oil. American Journal of Clinical Nutrition 63, 116-122.

Chan DC, Watts GF, Barrett PH, Beilin LJ \& Mori TA (2002) Effect of atorvastatin and fish oil on plasma high-sensitivity $\mathrm{C}$-reactive protein concentrations in individuals with visceral obesity. Clinical Chemistry 48, 877-883.

Christensen JH, Christensen MS, Dyerberg J \& Schmidt EB (1999) Heart rate variability and fatty acid content of blood cell membranes: a dose-response study with $n-3$ fatty acids. American Journal of Clinical Nutrition 70, 331-337.

De Caterina R, Liao JK \& Libby P (2000) Fatty acid modulation of endothelial activation. American Journal of Clinical Nutrition 71, 213S-223S.

Erlandsen EJ \& Randers E (2000) Reference interval for serum 
C-reactive protein in healthy blood donors using the Dade Behring N Latex CRP mono assay. Scandinavian Journal of Clinical Laboratory Investigation 60, 37-43.

Ernst E, Saradeth T \& Achhammer G (1991) n-3 Fatty acids and acute-phase proteins. European Journal of Clinical Investigation 21, 77-82.

James MJ \& Cleland LG (1997) Dietary $n$-3 fatty acids and therapy for rheumatoid arthritis. Seminars in Arthritis and Rheumatism 27, 85-97.

James MJ, Gibson RA \& Cleland LG (2000) Dietary polyunsaturated fatty acids and inflammatory mediator production. American Journal of Clinical Nutrition 71, 343S-348S.

Koenig W, Sund M, Frohlich M, Fischer HG, Lowel H, Doring A, Hutchinson WL \& Pepys MB (1999) C-Reactive protein, a sensitive marker of inflammation, predicts future risk of coronary heart disease in initially healthy middle-aged men: results from the MONICA (Monitoring Trends and Determinants in Cardiovascular Disease) Augsburg Cohort Study, 1984 to 1992. Circulation 99, 237-242.

Lee TH \& Austen KF (1986) Arachidonic acid metabolism by the 5-lipoxygenase pathway, and the effects of alternative dietary fatty acids. Advances in Immunology 39, 145-175.

Macy EM, Hayes TE \& Tracy RP (1997) Variability in the measurement of C-reactive protein in healthy subjects: implications for reference intervals and epidemiological applications. Clinical Chemistry 43, 52-58.

Madsen T, Skou HA, Hansen VE, Fog L, Christensen JH, Toft E \& Schmidt EB (2001) C-reactive protein, dietary $n-3$ fatty acids, and the extent of coronary artery disease. American Journal of Cardiology 88, 1139-1142.

Meier-Ewert HK, Ridker PM, Rifai N, Price N, Dinges DF \& Mullington JM (2001) Absence of diurnal variation of C-reactive protein concentrations in healthy human subjects. Clinical Chemistry 47, 426-430.

Nielsen GL, Faarvang KL, Thomsen BS, Teglbjaerg KL, Jensen LT, Hansen TM, Lervang HH, Schmidt EB, Dyerberg J \& Ernst E (1992) The effects of dietary supplementation with n-3 polyunsaturated fatty acids in patients with rheumatoid arthritis: a randomized, double blind trial. European Journal of Clinical Investigation 22, 687-691.

Ridker PM (2001) High-sensitivity C-reactive protein: potential adjunct for global risk assessment in the primary prevention of cardiovascular disease. Circulation 103, 1813-1818.

Ridker PM, Cushman M, Stampfer MJ, Tracy RP \& Hennekens CH (1997) Inflammation, aspirin, and the risk of cardiovascular disease in apparently healthy men. New England Journal of Medicine 336, 973-979.

Rifai N, Tracy RP \& Ridker PM (1999) Clinical efficacy of an automated high-sensitivity $\mathrm{C}$-reactive protein assay. Clinical Chemistry 45, 2136-2141.

Ross R (1999) Atherosclerosis-an inflammatory disease. New England Journal of Medicine 340, 115-126.

Schmidt EB (1997) $n-3$ Fatty acids and the risk of coronary heart disease. Danish Medical Bulletin 44, 1-22.

Schmid EB \& Dyerberg J (1989) $n$-3 Fatty acids and leucocytes. Journal of Internal Medicine 225, 151S-158S.

Schmidt EB, Pedersen JO, Varming K, Ernst E, Jersild C, Grunnet N \& Dyerberg J (1991) $n$-3 Fatty acids and leukocyte chemotaxis. Effects in hyperlipidemia and dose-response studies in healthy men. Arteriosclerosis and Thrombosis 11, 429-435.

Simopoulos AP (1999) Essential fatty acids in health and chronic disease. American Journal of Clinical Nutrition 70, 560S-569S.

Steel DM \& Whitehead AS (1994) The major acute phase reactants: C-reactive protein, serum amyloid $\mathrm{P}$ component and serum amyloid A protein. Immunology Today 15, 81-88.

Tataru MC, Heinrich J, Junker R, Schulte H, von Eckardstein A, Assmann G \& Koehler E (2000) C-reactive protein and the severity of atherosclerosis in myocardial infarction patients with stable angina pectoris. European Heart Journal 21, 1000-1008.

Toss H, Lindahl B, Siegbahn A \& Wallentin L (1997) Prognostic influence of increased fibrinogen and C-reactive protein levels in unstable coronary artery disease. FRISC Study Group. Fragmin during Instability in Coronary Artery Disease. Circulation 96, 4204-4210. 